\title{
Model Test Ultimate Bearing Capacity of Bakau Piles Foundation on Soft Soil Deposit
}

\author{
Muhammad Yunus ${ }^{\mathrm{a}, *}$ \\ aapepartment of Civil Engineering, Polytechnic State of Fakfak. Email: muhammadyunus@ polinef.id
}

\begin{abstract}
The pile foundation is one of the deep foundation types commonly used to support building loads when hard soil layers are deeply located. To determine the ultimate bearing capacity of a pile foundation of the load test results, there are several methods commonly used to interpretation test results such as Davisson method, Mazurkiewich method, Chin method, Buttler Hoy method and De Beer method. The aim of this study was to determine the characteristics of soft soil and bakau piles used in the study and to analyze the size of the bearing capacity ultimate of pile foundation that is modeled on a small scale in the laboratory. From the test results of material characteristics of the soil used is organic clay type with medium plasticity with specific gravity 2.75 , liquid limit, $L L=50.36 \%$ and plasticity index, $P I=13.2 \%$. While the results of testing the characteristics of bakau piles obtained average water content of $21.58 \%$, tensile strength of $18.51 \mathrm{MPa}$, compressive strength of parallel fiber $23.75 \mathrm{MPa}$ and perpendicular fiber $14.10 \mathrm{MPa}$, bending strength 106.22 MPa, and strong split 29.91 MPa. From the result of loading test of the foundation model in the laboratory, it is found that the ultimate bearing capacity of the model without foundation is $41.00 \mathrm{kN}$ with the ultimate settlement of $14.00 \mathrm{~mm}$, the model of the 20 $\mathrm{cm}$ long bakau piles foundation is $52.00 \mathrm{kN}$ with the ultimate settlement of $13.00 \mathrm{~mm}$, the foundation model a $30 \mathrm{~cm}$ long bakau piles foundation of $54.00 \mathrm{kN}$ with a $10.00 \mathrm{~mm}$ ultimate settlement, a $40 \mathrm{~cm}$ long bakau piles foundation model of $56.00 \mathrm{kN}$ with an ultimate settlement of $8.50 \mathrm{~mm}$
\end{abstract}

Keywords: Bakau piles; bearing capacity; loading test; piles foundation

\section{Introduction}

As a result of development especially building of public works infrastructure sector, so the need of land for development will also continue to grow. In large cities to meet these needs inevitably the development must be done on very soft soil and sometimes even to reclaim the beach. Soft clay and very soft clay have properties such as tend to be very compressible, low shear strength, low permeability, and have low bearing capacity. It is these qualities that become the main problem of planners if they will build a structure on it.

To overcome the existing problems, the planners usually use the stake for the construction of the foundation. The use of piles is commonly used to overcome the impossibility of using shallow foundations and overcome land subsidence. The use of piles is commonly used to overcome the impossibility of using shallow foundations and overcome land subsidence. In addition other reasons for the use of piles are the easy workmanship, the inventory in many plants, and the formulation of carrying capacity can be estimated by the existing formulas.

Judging from the way to support the load, the pile foundation is divided into 2 (two) kinds [1].

* Corresponding author. Tel.: +62-811-4212-748

Jalan TPA Imam Bonjol Atas Air Merah, Kelurahan Wagom

Fakfak, Papua Barat, Indonesia, 98611
1. End bearing pile, is a pile whose support capacity is more determined by the pole end resistance.

2. Friction pile, is a pile whose capacity is determined friction resistance between the pole side and the surrounding ground.

Indonesian is one of the countries that has tropical climate and has a vast forest area, so that Indonesia is a country that is very rich in wood materials both types and quantities and can be utilized as pile foundation material. The commonly used wooden pile foundation generally has a diameter of $10-25 \mathrm{~cm}$, while for cerucuk wood piles are widely used in Indonesian to increase the soft soil bearing capacity of $8-15 \mathrm{~cm}$ in diameter and 4 meters in length.

Many advantages derived from the use of wood piles, among others [2]:

1. Pile is relatively light so easy to transport.

2. Tensile strength so that at the time in the lift for erection does not cause difficulties as in the pile of concrete precast.

3. Easy to cut if wooden pole can not enter again into the ground.

4. Wooden piling is more suitable for friction pile than end bearing pile because the pressure is relatively small.

In addition to the above advantages, there are some shortcomings of the use of wooden piles, among others [2]: 
1. Since this pile must always be located under the lowest groundwater level for long lasting, so if the groundwater is the lowest it is located very deep, it will increase the cost for excavation.

2. Wooden piles are of relatively small lifespan compared to concrete or steel piles, especially in areas where the water level is often up and down.

3. At the time of erection on the rocky ground (gravel) the end of the wood pile can be shaped in the form of a broom or can also tip the pole is crushed, if the wooden pole is less straight then at the time of placement will cause deviations against the direction that has been specified.

4. Wooden piles are not resistant to aggressive objects and fungi that cause decay.

\section{Literature Review}

\section{a. Ultimate bearing capacity}

Ultimate bearing capacity can be defined as the smallest pressure that can cause shear failure on the supporting ground just below and around the foundation. There are three types of failure that have been identified and described in relation to the bearing capacity of the soil with reference to Fig. 1 [3].

1. General shear failure. This failure will occur when pressure is raised to achieve the initial plastic equilibrium conditions on the ground around the sides of the foundation and then gradually spread down and out. Finally, the ultimit plastic state of balance will form along the ground above the failure plane. The ground surface on both sides of the field that receives the load is lifted. The way this collapse occurs on low-compressed soil is tight or rigid soil.

2. Local shear failure. There is considerable compression in the soil beneath the burdened plane and the plastic equilibrium state is formed only in part of the soil alone. The failure surface does not reach the surface, and there is little ground lifting. Local shear failure usually occurs on highly compressible soil and is marked by a relatively large decline, and the fact that ultimit support capacity can not be defined.

3. Punching shear failure. Occurs if there is compression under the plane that accepts the load accompanied by the vertical shift around it. This failure is characterized by a relatively large decline, and an undefined ultimate bearing capacity.

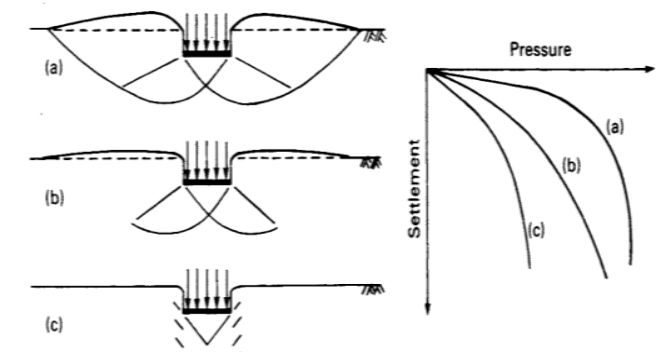

Figure 1. Types of failure, (a) general shear failure, (b) local shear failure, (c) punching shear failure [3]

\section{b. Soil settlement}

Settlement on the soil is inseparable from the incompressibility of the soil. On coarse grained soils and pores filled with water when receiving the load will decrease immediately. This happens because the water in the pore will be faster out through the crack of coarse grained soil. While on fine-grained soil and pores filled with water, the decrease that occurs due to the load will be slower than coarse grained soil. This happens because water will be difficult to pass through the smaller pore. In the field of geotechnical engineering, this settlement is differentiated in the following types [4].

1. Immediate Settlement

2. Primary Consolidation Settlement

3. Seconday Consolidation Settlement

\section{c. Pile loading test}

In principle, this pile loading procedure is performed by providing a vertical load placed over the head of the pile, then the magnitude of the vertical deformation occurring is measured using a dial mounted on the pile. The deformation that occurs consists of elastic and plastic deformation. The elastic deformation is a deformation caused by the elastic shortening of the pole and the ground, whereas plastic deformation is a deformation caused by the collapse of the supporting ground on the tip or around the pile. If the relationship between the deformation and the load is represented in the curve it will be seen that the graph will consist of 3 (three) parts as shown in Fig. 2 [5].

\section{Research Methodology}

\subsection{Soil characteristic test}

Testing of soil characteristics carried out in the laboratory among others, water content test, volume weight, specific gravity, Atterberg limits, sieve analysis, hydrometer test, compaction, unconfined compression strength and direct shear test.

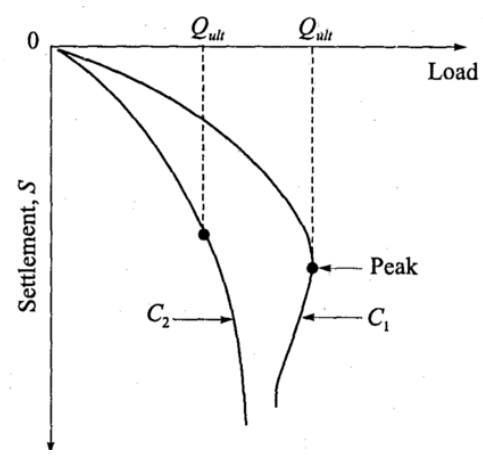

Figure 2. Load vs settlement [5] 


\subsection{Bakau pile characteristic test}

Testing of wood characteristics carried out in the laboratory, among others, testing the moisture content, flexural strength, tensile strength, compressive strength and strength of split. For each test, wood samples were prepared for 3 (three) samples. From the results of testing the characteristics of bakau can be classified strong grade of bakau wood used in this study.

\subsection{Preparation of foundation model in laboratory}

The modeling of the foundation in the laboratory consists of 4 (four) variation model, model without reinforcement of pile foundation, model with reinforcement of pile foundation with pole length 20 $\mathrm{cm}, 30 \mathrm{~cm}$ and $40 \mathrm{~cm}$.

- Soil model without reinforcement of pile foundation

Soft clay that has been tested its characteristics inserted into the drum with a diameter of $60 \mathrm{~cm}$ and height $60 \mathrm{~cm}$. Then compacted perlayer with a thickness of $10 \mathrm{~cm}$ perlayernya to a height of $50 \mathrm{~cm}$ with a density of $80 \%$ of the maximum density obtained from standard compaction tests that have been carried out in the laboratory. After that put plate loading test with diameter plate size of $30 \mathrm{~cm}$ and plate thickness of 1.5 $\mathrm{cm}$ as seen in Fig. 3 .

Attach dial gauge 3 (three) pieces, above the plate bearing test of 1 piece to read the settlement and 2 (two) pieces each in addition to the plate loading test to read the deformation that occurs. The burden on the foundation model is done by using hydraulic jack until the failure occurs while the dial gauge reading is done according to the amount of load given until the collapse occurs on the ground.

- Soil model with pile foundation length $20,30,40 \mathrm{~cm}$

Subsequently the soil model in the drum was dismantled and the clay that has been tested its characteristic was inserted into the drum and then compacted the perlayer with a thickness of $10 \mathrm{~cm}$ perlayer to a height of $50 \mathrm{~cm}$ with a density level of $80 \%$ of the maximum density obtained from the standard compaction test that has been carried out in the laboratory.

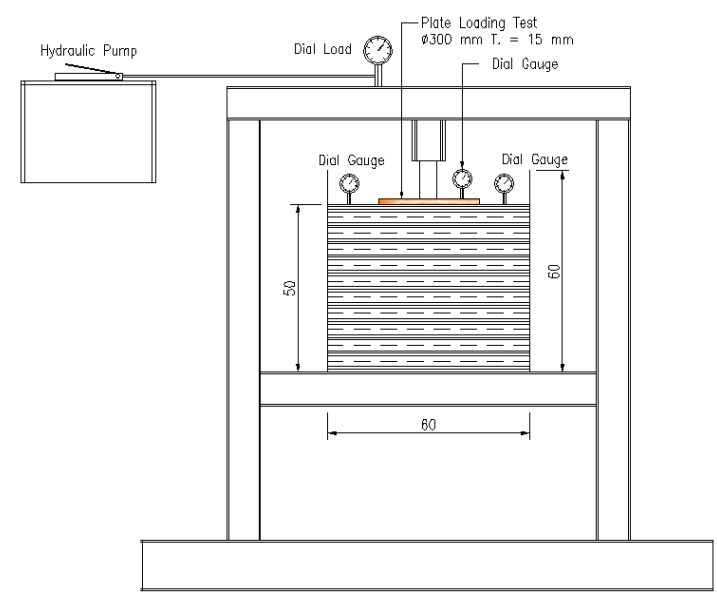

Figure 3. Model without of pile foundation

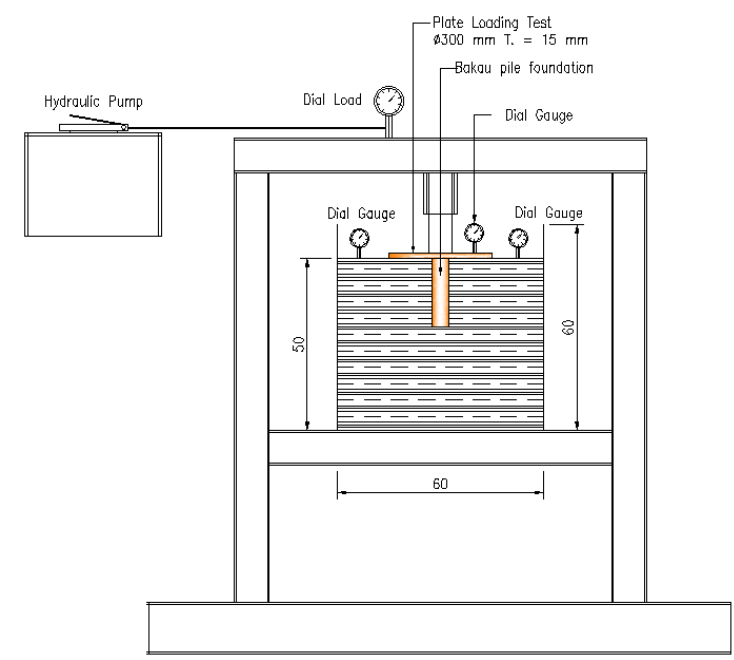

Figure 4. Model pile foundation

After that pile wooden mast with wood diameter about $3-5 \mathrm{~cm}$ which will be used as a single pole foundation with size of pole length which is $20 \mathrm{~cm}, 30$ $\mathrm{cm}$ and $40 \mathrm{~cm}$ as in Fig. 2. Then put plate bearing test with diameter plate size $30 \mathrm{~cm}$ and $1.5 \mathrm{~cm}$ thick plate above the mast pole that has been fixed as seen in Fig. 4.

Attach dial gauge 3 (three) pieces, above the plate bearing test of 1 piece to read the settlement and 2 (two) pieces each in addition to the plate loading test to read the deformation that occurs. The burden on the foundation model is done by using hydraulic jack until the failure occurs while the dial gauge reading is done according to the amount of load given until the collapse occurs on the ground.

\section{Result and Discussion}

\subsection{Testing results of soil characteristics}

From the results of soil characteristics test obtained data in Table 1.

Table 1. Testing results of soil characteristics

\begin{tabular}{|c|c|c|}
\hline Types of testing & Unit & Result \\
\hline Water content & $\%$ & 36.00 \\
\hline Spesific gravity & - & 2.75 \\
\hline \begin{tabular}{ll}
\multicolumn{2}{l}{ Atterberg Limit } \\
a. & Liquid Limit (LL) \\
b. & Plastic Limit (PL) \\
c. & Plasticity Index (PI) \\
d. & Shrinkage Limit (SL)
\end{tabular} & $\begin{array}{l}\% \\
\% \\
\% \\
\%\end{array}$ & $\begin{array}{l}50.36 \\
37.23 \\
13.12 \\
29.86\end{array}$ \\
\hline $\begin{array}{l}\text { Grain of Soil } \\
\text { a. Soil grained coarse } \\
\text { b. Soil grained fine } \\
\end{array}$ & $\begin{array}{l}\% \\
\% \\
\end{array}$ & $\begin{array}{l}45.90 \\
54.10 \\
\end{array}$ \\
\hline 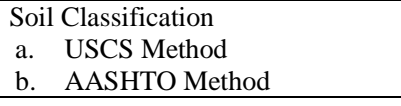 & - & $\begin{array}{c}\mathrm{MH} \& \mathrm{OH} \\
\mathrm{A}-7-5\end{array}$ \\
\hline Unconfined compression test $\left(\mathrm{q}_{\mathrm{u}}\right)$ & $\mathrm{kg} / \mathrm{cm}$ & 0.72 \\
\hline $\begin{array}{l}\text { Compaction } \\
\text { a. Water content optimum }\left(\mathrm{w}_{\mathrm{opt}}\right) \\
\text { b. Weight volume dry }\left(\gamma_{d r y}\right)\end{array}$ & $\begin{array}{c}\% \\
\mathrm{gr} / \mathrm{cm}^{3}\end{array}$ & $\begin{array}{c}41.75 \\
1.22 \\
\end{array}$ \\
\hline $\begin{array}{l}\text { Direct shear } \\
\text { a. Cohesion }(c) \\
\text { b. Internal friction angle }(\phi)\end{array}$ & $\begin{array}{c}\mathrm{kg} / \mathrm{cm}^{2} \\
0\end{array}$ & $\begin{array}{l}0.104 \\
17.32 \\
\end{array}$ \\
\hline
\end{tabular}


Table 2. Testing results bakau wood characteristics

\begin{tabular}{lcc}
\hline \multicolumn{1}{c}{ Types of testing } & Unit & Result \\
\hline Moisture content & $\%$ & 21.580 \\
\hline Tensile strength & $\mathrm{MPa}$ & 18.515 \\
\hline $\begin{array}{l}\text { Modulus of elasticity } \\
\text { tensile strength }\end{array}$ & $\mathrm{MPa}$ & 690.423 \\
\hline $\begin{array}{l}\text { Compressive strength } \\
\text { parallel fiber }\end{array}$ & $\mathrm{MPa}$ & 23.757 \\
\hline $\begin{array}{l}\text { Modulus of elasticity } \\
\text { parallel fiber }\end{array}$ & $\mathrm{MPa}$ & 964.596 \\
\hline $\begin{array}{l}\text { Compressive strength perpendicular } \\
\text { fiber }\end{array}$ & $\mathrm{MPa}$ & 14.710 \\
\hline $\begin{array}{l}\text { Modulus of elasticity } \\
\text { perpendicular fiber }\end{array}$ & $\mathrm{MPa}$ & 591.230 \\
\hline $\begin{array}{l}\text { Bending strength } \\
\text { Strong split }\end{array}$ & $\mathrm{MPa}$ & 106.224 \\
\hline
\end{tabular}

\subsection{Testing results of bakau wood characteristics}

From the test results of bakau material characteristics obtained data in Table 2.

While from the results of X-Ray Diffraction testing can be known mineral composition contained in bakau wood as shown in Fig. 5. The results of testing the composition of bakau wood materials showed that the wood-forming minerals are Silicate (SiO2), Aluminum (A12O3), Sodium (Na2O), Magnesium (MgO), Potassium (K2O), Sulfur (SO3), Phosporus (P2O5) and Chlorine.

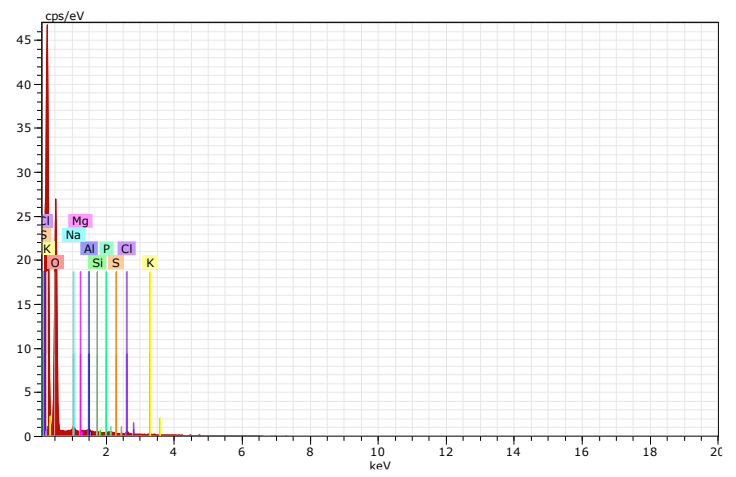

Figure 5. X-Ray Diffraction test results of bakau wood
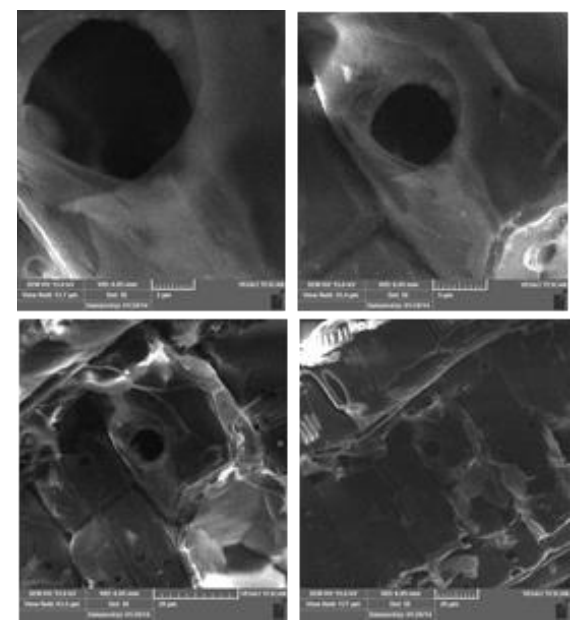

Figure 6. SEM (Scanning Electron Microscope) tes result bakau wood

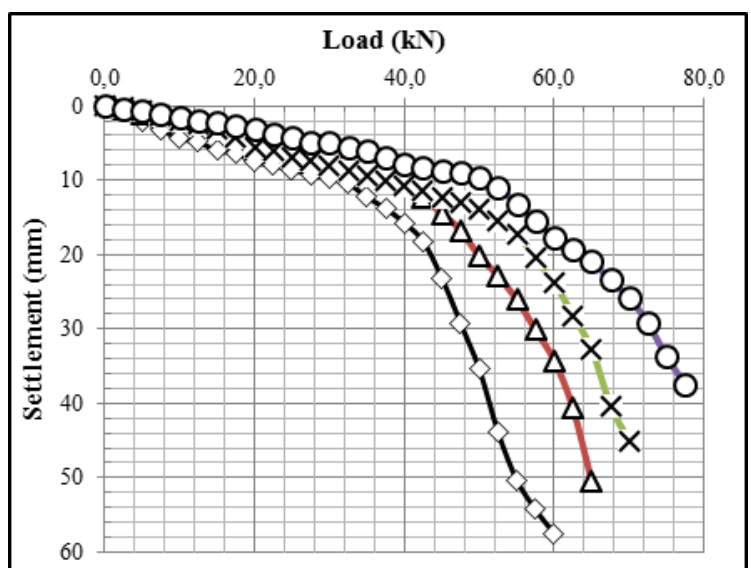

Figure 7. Load vs. settlement

From SEM (Scanning Electron Microscope) testing is a test used to view the microstructure that is formed, both for surface and transverse cross section. The SEM test result of bakau wood material is shown in Fig. 6.

\subsection{Loading test result of foundation model}

From the result of loading test of the foundation model in the laboratory obtained the graph of the load relationship vs. the decline of the foundation model as seen in Fig. 7.

The graph in Fig. 7 shows that at the beginning of the loading the decline is relatively small. This decrease is caused by elastic shape changes in the surrounding soil. If the load is added to the decrease that occurs faster until it reaches its maximum limit and the ground failure.

\subsection{Ultimate bearing capacity analysis}

In determine the value of ultimit bearing capacity $\left(Q_{u l t}\right)$ of each model of the loaded loaded foundation used Butler and Hoy method (1977). This method considers the load failure when the load occurs the intersection of two tangent lines against the relation curve between load vs. settlement at different points. The first tangent line is the initial straight line assumed as an elastic pressure line. For the second tangent line obtained is limited as a slope of $0.05 \mathrm{kN}$ on the load vs. settlement graph [7].

- Soil model without reinforcement of pile foundation

To determine the ultimate bearing capacity $\left(Q_{u l t}\right)$ soil without foundation model, we create a graph of load vs. settlement as seen in Fig. 8. From the graph in Fig. 8 using the Butler and Hoy method, the value of ultimate support capacity $\left(Q_{u l t}\right)$ is $41.00 \mathrm{kN}$ with ultimate settlement $\left(\delta_{u}\right)$ obtained at $14.00 \mathrm{~mm}$.

- Soil model with pile foundation length $20 \mathrm{~cm}$

To determine the ultimate bearing capacity $\left(Q_{u l t}\right)$ of the foundation model with a length of $20 \mathrm{~cm}$ pile then made the graph of load vs. settlement as seen in Fig. 9. From the graph of load vs. settlement in Fig. 9 using the Butler and Hoy method obtained the value of ultimate bearing capacity $\left(Q_{u l t}\right)$ of $52.00 \mathrm{kN}$ with ultimate settlement $\left(\delta_{u}\right)$ obtained at $13.00 \mathrm{~mm}$. 


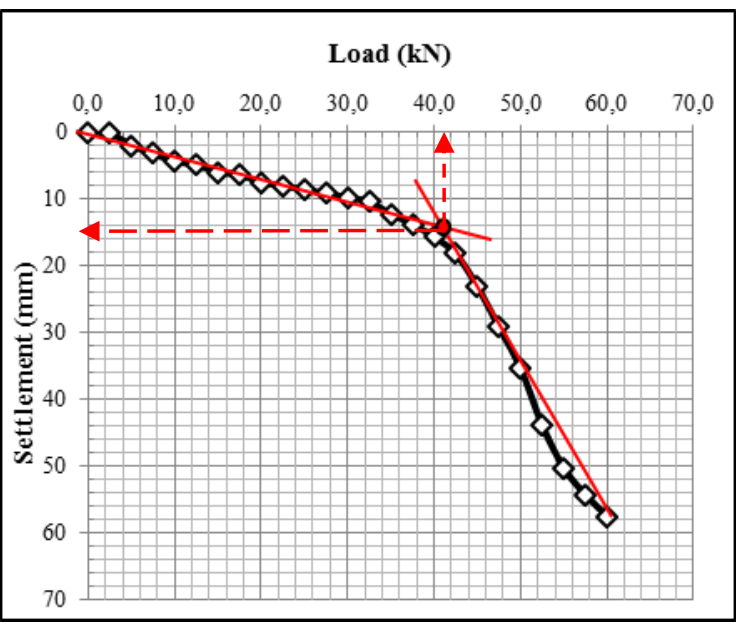

Figure 8 . Ultimate bearing capacity determination of soil model without foundation

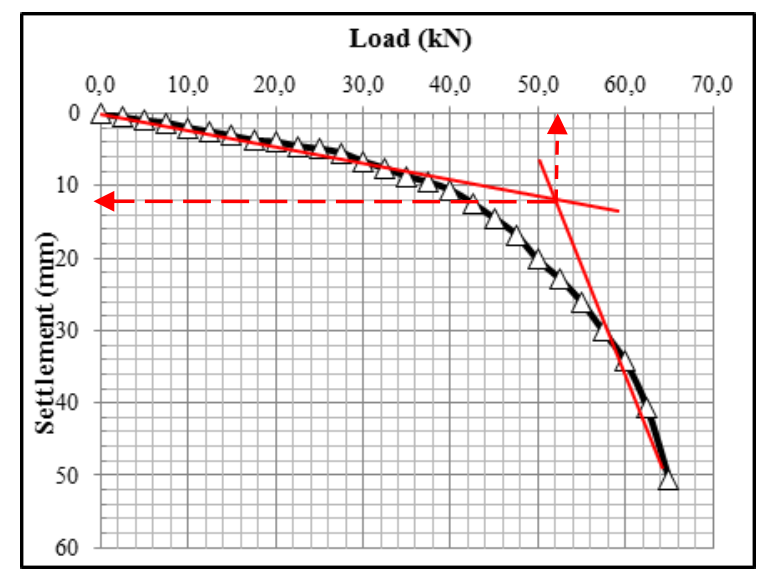

Figure 9. Ultimate bearing capacity determination of pile foundation model pile length $20 \mathrm{~cm}$

- Soil model with pile foundation length $30 \mathrm{~cm}$

To determine the ultimate bearing capacity $\left(Q_{u l t}\right)$ of the foundation model with a length of $30 \mathrm{~cm}$ pile then made the graph of load vs. settlement as seen in Fig. 10. From the graph of load vs. settlement in Fig. 10 using the Butler and Hoy method obtained the value of ultimate bearing capacity $\left(Q_{u l t}\right)$ of $54.00 \mathrm{kN}$ with ultimate settlement $\left(\delta_{u}\right)$ obtained at $10.00 \mathrm{~mm}$.

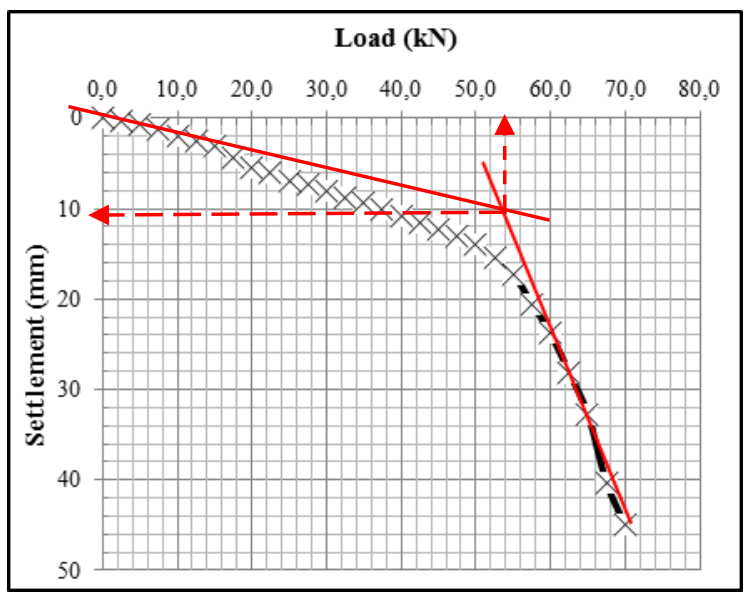

Figure 10. Graph of ultimate bearing capacity determination of pile foundation model length $30 \mathrm{~cm}$

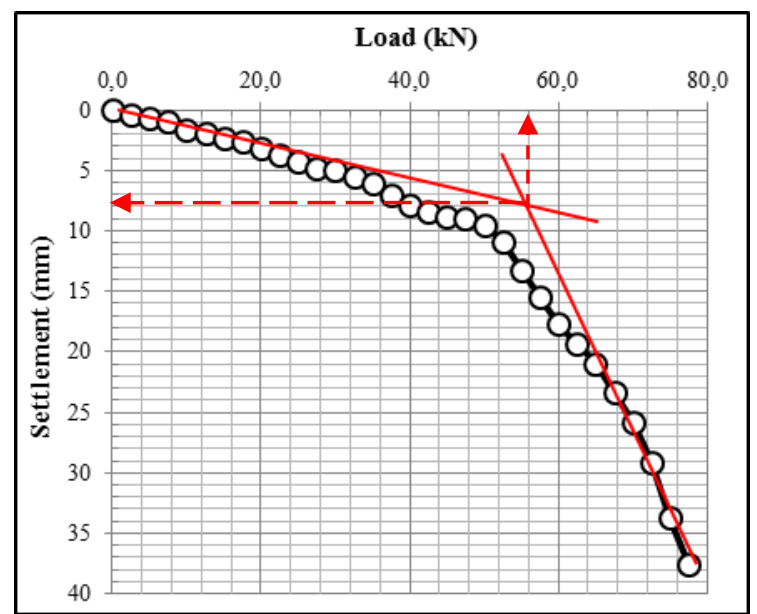

Figure 11. Ultimate bearing capacity determination of pile foundation model pile length $40 \mathrm{~cm}$

- Soil model with pile foundation length $20 \mathrm{~cm}$

To determine the ultimate bearing capacity $\left(Q_{u l t}\right)$ of the foundation model with a length of $40 \mathrm{~cm}$ pile then made the graph of load vs. settlement as seen in Fig. 11. From the graph of load vs. settlement in Fig. 11 using the Butler and Hoy method obtained the value of ultimate bearing capacity $\left(Q_{u l t}\right)$ of $56.00 \mathrm{kN}$ with ultimate settlement $\left(\delta_{u}\right)$ obtained at $8.50 \mathrm{~mm}$.

From the results of model testing in the laboratory capacity of foundation of bakau pile obtained foundation model of bakau pile wood with length of pile of $40 \mathrm{~cm}$ have the biggest capacity of support (Qult) compared to other foundation model.

\section{Conclusion}

Based on the test results and data analysis that has been implemented, the following conclusions can be drawn:

1. From the test of material characteristics, the soil used is organic clay type with medium plasticity with value of specific gravity $(G s) 2.75$, liquid limit $(L L)=50.36 \%$ and plasticity index $(P I)=13.12 \%$. While the result of dolken wood characteristic test obtained water content average $21.58 \%$, tensile strength $18.51 \mathrm{MPa}$ wood, compressive strength of wood parallel fiber $23.75 \mathrm{MPa}$ and perpendicular fiber $14.10 \mathrm{MPa}$, wood bending strength 106.22 $\mathrm{MPa}$, and wooden strength $29.91 \mathrm{MPa}$. Given a strong class of wood entering into a strong class of wood II.

2. From the result of load test of foundation model in laboratory get value of ultimate bearing capacity of model without foundation of $41.00 \mathrm{kN}$ with decreasing ultimit $14.00 \mathrm{~mm}$, model of $20 \mathrm{~cm}$ long pole foundation $52.00 \mathrm{kN}$ with decreasing ultimit $13.00 \mathrm{~mm}$, model of $30 \mathrm{~cm}$ long pole foundation $54.00 \mathrm{kN}$ with a $10.00 \mathrm{~mm}$ ultimit decrease, a $40 \mathrm{~cm}$ long pole foundation model of $56.00 \mathrm{kN}$ with an $8.50 \mathrm{~mm}$ ultimit decrease. 


\section{References}

[1] Bowles, J.E., (1996), Foundation Anaysis and Design, McGrawHill, New York.

[2] Craig, R.F., (2004), Soil Mechanics, Erlangga, Jakarta.

[3] Das, Braja M., (1990), Principles of Foundation Engineering, PWS-KENT Publishing Company, Boston.

[4] Hardiyatmo, H.C., (2010), Foundation Analysis and Design 1 dan 2, Gadjah Mada University Press, Yogyakarta.

[5] Murthy, V.N.S., (2007), Advanced Foundation Engineering, CBS Publishers \& Distributors, New Delhi Bangalore.

[6] Poulos, H.G. \& Davis, E.H., (1980), Pile Foundation Analysis and Design, John Wiley \& Sons, New York.

[7] Prakash, S., Sharma D., (1990), Pile Foundation in Engineering Practice, John Wiley \& Sons, Inc., New York.
[8] Rahardjo, Paulus P., (2005), The Use of Bamboo and Bakau Piles for Soil Improvement and Application of Pile Raft System for the Construction Embankments on Peats and Soft Soils, Elsevier Geo-Engineering Book Series Volume 3, London.

[9] Standar Nasional Indonesia, (1994), Methods of Testing Wood Tensile Strength in the Laboratory, SNI-03-3399-1994, Badan Standardisasi Nasional.

[10] Standar Nasional Indonesia, (1995), Methods of Testing Wood Compressing Strength in the Laboratory, SNI-03-3958-1995, Badan Standardisasi Nasional.

[11] Standar Nasional Indonesia, (1995), Methods of Testing Wood Bending Strength in the Laboratory, SNI-03-3959-1995, Badan Standardisasi Nasional.

[12] Standar Nasional Indonesia, (2002), Procedure for Measurement of Wood Water Content and Woody Material, SNI-03-68502002, Badan Standardisasi Nasional. 